\title{
CHANGES PRODUCED IN THE SUPERIOR CERVICAL AND CAELIAC SYMPATHETIC GANGLIA BY IRRITATION OF THE LIP IN GUINEA PIGS.
}

\author{
By \\ T. INOUE \\ From the Department of Otorhinolaryngology, School of Medicine, Keio \\ University (Director: Prof. T. Nishihata)
}

1) In guinea pig, the lip was irritated with repeated injection of croton oil for various length of time, and the changes produced in the lip, superior cervical and caeliac sympathetic ganglia, and various organs were investigated histopathologically.

2) In the first group of animals to which croton oil was injected for a short period of time, only edema of the lip was observed, whereas in the second group to which injection was repeated. for longer period, necrosis and/or cicatrix formation were remarkable.

3) The sympathetic ganglia showed little change in the animals of the first group, while in the second group they showed degenerative changes mainly consisting of atrophy and swelling of the cells,.. vacuolization or destruction of the cytoplasma, chromatolysis, swelling, atrophy, deformation and destruction of nuclei. The longer the lip was exposed to the irritation the higher was the degree of the changes. Changes in the superior cervical and caeliac sympathetic ganglia were similar to each. other.

4) In various organs changes due to circulatory disturbance such as congestion and hemorrhage aswell as various degenerative changes were observed. These changes were more pronounced in group I.

5) On the basis of these findings, the author explained the shock symptoms produced by irritation of the lip as a manifestation of Reilly's phenomena, and offered a postulation that the irritation to the lip was transmitted to the autonomic nervous system of the entire body through the superiorcervical ganglion working as one of the mediators of the stimulus transmission.

6) Further more, the cause of novocain shock was discussed clinically from the viewpoint of: Reilly's theory.

\section{モルモツトロ唇過剩剌戟による頸部並びに 腹腔交感神経節の変化について}

\section{蔯応義塾大学医学部耳鼻咽喉科学教室（主任：西端臨一教授）}

井卡奉 樹

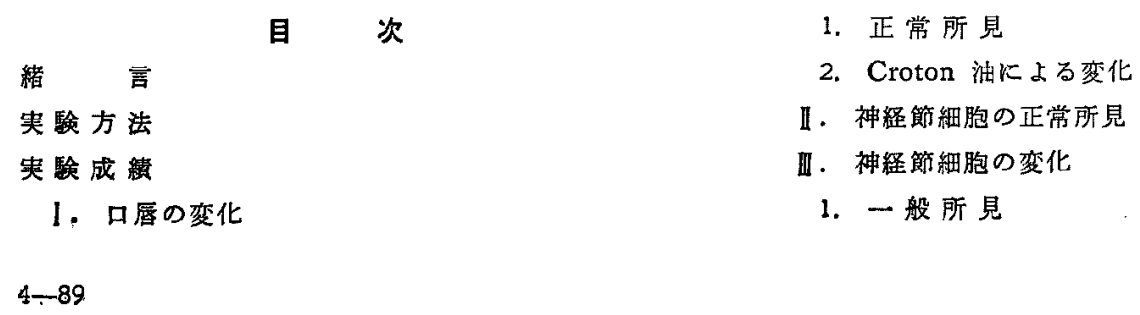


2. 各群神经節細胞の所見
a. 第 I 群 $(2 \sim 3$ 時間群)
b. 第 II 群 (5 日群)
c. 第 III 群 (10日群)
d. 第 $\mathrm{N}$ 群 (20日群)

N.内臟々器の所見

総括並びに考按

結語

\section{緒言}

生体は外部よりの軣々の刺战に対処して，自らを防禦

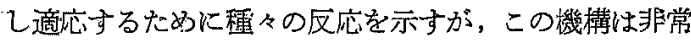
に微妙でかつ複雑なため，これを解明することは容易で

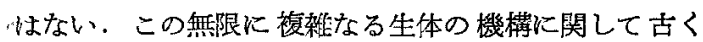
忙 Claude Bernard 仗人間内部環境の恒常性をとき4)， Cannon は1929年 Homeostesis を, Selye 1936 年 Stress 学説を提唱し 18１4）42) 59)，習慣的機能の自働的 調節が重要なことを呈示している。これより先に Reil-

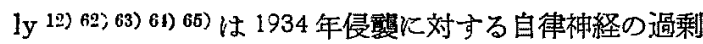
刺㦸による生体の非特異的な症候について述心゙，さら 《 Laborit 7) は侵覘後の生体反応体系について報告し ている。しかし，自らを防毦し適応せ九とする生体の反 応にも限度があり，この刺钱が強すざるときは，乙ばし ば生体は自らを破綻に遒く

従来上り研究されている Shock としては出血性 Shock 21), Anaphylaxy Shock 43), 外傷性 Shock などがあ げられるが，我々が耳鼻咽喉程領域の手術的操作に上り 経験する Shock とは大分趣を異にしている，我々が取 扱う頭部及び頸部は H. Stolze 17) の指摘せるごとく脳 々軀幹の尰絡路にあたり脈管系にとみ，生体の重要な場

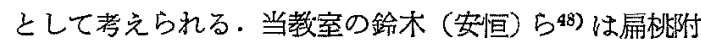
近や頸部の手術時には他の部より急性死の症例が多いこ とをみとわ，かつ，Shock 死症例の統計的観察と病理 学的検索の結果，彼はとくに神経系統の過剩症，あるい

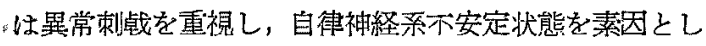
て考えている.

飯田 ${ }^{27)}$ はこの考点に基き, Speransky ${ }^{15)}$ の方法を 応用し，モルモットロ屡粘膜下及び腹部皮下に Croton 油索注射し薏起される Shock について詳細なる検 討を行い，染沢 26) は Chlorpromazin を用いてこれを 阻止し，ともに口唇の特珠性と起される Shock の原因 として Reilly の説く自律神経末梢の刺战が関与するの ではないかと説べている、私は口唇に Croton 油を注射 したとき，この支配領域の上頸部交感神経節に何等かの
桻㦸が加わり，さらに全身の自律神経系を介して内荿諸 臟器に変化を萑起するのではないかという考党により， 種々の期間 Croton 油にて口唇粘膜を刺婑した際の上頸 部及び腹腔交感神経節細湀:，ならびに内臓諸臓器と局所 口唇の病理租繶学的変化を检索し，若干の知見をえたの でこ〉報告する。

\section{実験方法}

枌料は体重 250 ないし 350る の健康なモルモットを使 用し，性別は特に考慮せず，これを 4 群に分けて次の実 駼を行つた。

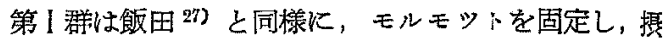
子を用いて開口，1/2mm 針を使用した皮内注射器にて 日唇粘膜下にCroton 油原液 $0.1 \mathrm{cc}$ を注射した。 この 際毎回 Croton 油が血管内に入らないことを確認した. この群の動物は飯田の報告の如く，約 $1 / 3 か ゙$ 注射後 2 特 間以内に死亡したが，死亡例は值らに剖検し，また生存 例は注射後 2 ないし 3 時間後に後頭部を吅打して剖検に 附した。

第 II 群は 5 日間観察したものを用いた。すなわる， Croton 油原液を隇菌オリーブ油にて 10 㥉にらすか, こ れを3日に $0.1 \mathrm{cc}$ 注射し，5日後に剖榆した。第田君は4日に1度 注射して 10 日後に，さらに第 $\mathrm{N}$ 群は 5 日に 1 度注射し て20日後にそれぞれ剖検した。

以上の操作は第 1 表の如くである.

第 1 表 実 就 方 法

\begin{tabular}{|c|c|c|c|c|c|c|}
\hline & $\Rightarrow$ & 口 & 1 & 2 & 油 & \multirow{2}{*}{ 観察期間 } \\
\hline & 1 回量 & 回数 & 間 & 隔 & 総量 & \\
\hline 第 I 群 & $0.1 \mathrm{cc}$ & 1 回 & & & $0.1 \mathrm{cc}$ & $2 \sim 3$ 時間 \\
\hline 第【群 & $0.01 \mathrm{cc}$ & 2 回 & 3 日 & 1 回 & $0.02 \mathrm{cc}$ & 5 日 \\
\hline 第 政群 & $0.01 \mathrm{cc}$ & 3 回 & 4 日 & 1 回 & $0.03 \mathrm{cc}$ & 10 日 \\
\hline 第 $\mathbb{N}$ 群 & $0.01 \mathrm{cc}$ & 4 回 & 5 日 & 1 回 & $0.04 \mathrm{cc}$ & 20 日 \\
\hline
\end{tabular}

な特，注射した Croton 油は口長皮蜀部，粘膜部及び 口蓋の前部にかけて腫瘤を作り，第【群以下では初回注 射のため同部は潰瘍状となり，2 回目以後の注射は困喤 を伴い, Croton 泊が外部にもれるむのるかなりあつた が，これは充分にふきとり，鱟下しないように注意し た. 又観察期間中死亡するものもあつたが・死後変化の 和それのあるるのは全て除き，死亡直後のむのと生存例 について実験成果を㭘討した。

採取した神経節は上頸部並びに腹腔交感神経節で，腹 
陵神経節は腸間膜，腹膜にて蔽われ，識別困難にて，採 取不能のものがかなりあつた。また同時に内葴諸蔵器の

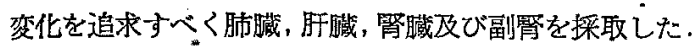
神経節の固定には 10\% Formalin, 純 Alcohol 及び 80\% Alcohol を使用し, Paraffin または Celloidin 包 埋の上, Hämatoxylin-Eosin 染色, Nissl 染色, AzanMallory 染色, 過沃度酸 Schiff 法 (Pas 染色), Methylgreen-Pyronin 染色などをほどこした。内臟諸臟器 と口唇は 10\% Formalin 固定後 Paraffin 包埋を行い， Hämatoxylin-Eosin 染色, Azan-Mallory 染色, 過沃 度酸 Schiff 法を行つた。

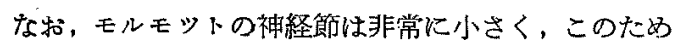
同一動物，同一標本にて华程の固定，包圤，染色法を同 時に施行することが不可能であり，従つて各種の染色法 にて同一標本を比較することは不可能であつた。

\section{実 験成綪}

\section{I. 口唇の变化}

1. 正常所見

モルモットロ唇は共同郁究者大野 40)によれば前, 中，

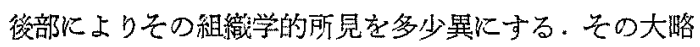
を引用すれば，

表皮は角化扁平上皮よりなり，真皮結合緥の発盲は場 所によりその密度を異にする。一般に乳頭の登育は良挍 で，乳頭内には豊富な血管網が形成されている。真皮内 には毛根，皮满附属腺をみとめ，真皮を形成する結合織 には翏原線維, 弾力線維及び好銀線維が介在し, 毛根周 囲にては密な弾力湶維網をみとめる. 皮下組織は場所に より蹯または密な結合織よりなり，多数の横紋筋楾維束 をみとめる・皮下脂肪組織は前部より後部に移行するに つれて漸次豊富となる．真皮と皮下組織の間，ならびに 乳頭下部には密な血管網が形成されている。

\section{Croton 油汇上る変化}

Croton 油注射後 2 3 時間の 組織学的変化では, 表

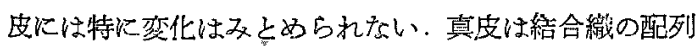
が粗となり，注射部位にわたつて広範に浮腫がみとめら れ，さらに皮下組織には真皮より連続した浮腫がみとめ られ，筋線維も一部断裂し，横紋が乱れている。一般に

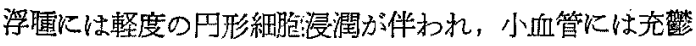
血がみとめられるが，腺細腿には変化が見られず，排泄 管にも分琕物の賩溜はみとめられない。

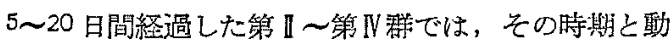
物により所見を異にし，潰瘍形成及び埕死の著明なもの と洀痕形成を示すをのとが見られる。
潰燩形成例では，注射部位の表皮は，ほとんど脱落を 示し，一部残つているものにも強い変化がみとめられ

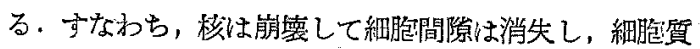

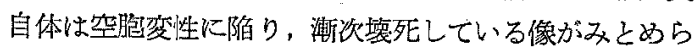

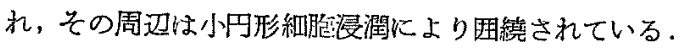

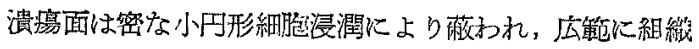

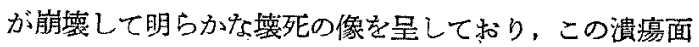
下部に脂肪組繶が存在しているが，これらは比較的原形 を留めているが，䟺澺と接する部に近い脂肪組穖は漸次 崩壞し，緗肥浸潤に置換されている。この脂肪組織に接 して樍紋筋束があるが，これはやう粗となるのみにて著。 明な变化はみとめられない，溑湯面と接する筋線維には 離断が著明に欢とめられ，末た変性も著しい，また一部”

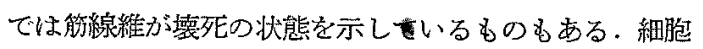
浸潤は主として小円形細起からなるがかなり大形の好中

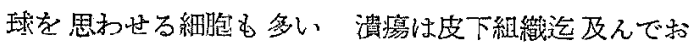
り，皮下組織は一部では浮䐈の非常に堷明な所見も見ら

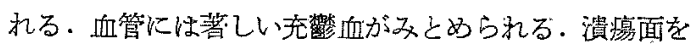
蔽う結合䋹が一部增殖している所もみとめられる。

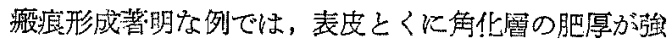
く，また剔離脱落も顕著であり，表皮細胞は形態不規則 で形も大きく，上層にゆくにつれて細胞の形態が明らか でなくなつている，一般に上皮内には遊走細胞をほをん

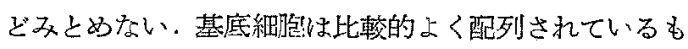
のと乱れているむのとがみとめられる．真皮は結合織の 增生が盛んで，幼若な線維氷細胞がみとめられ，一部で

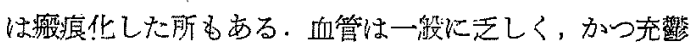
血は少なく，血管内皮は肥厚著明で，小円形細䏲浸潤は なおびをん性にみとめられる。

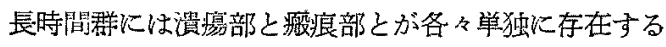

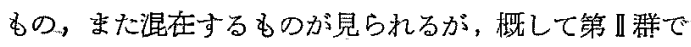

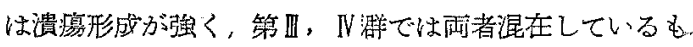
のが多く見ら机る。

\section{I1 神経節細胞の正常所見}

Hämatoxylin-Eosin 染色炕上る上頸神経節絓脃の正

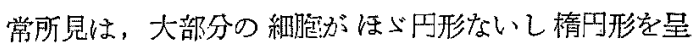
し，原形質は Eosin にて染まり，その周辺部に塩基性

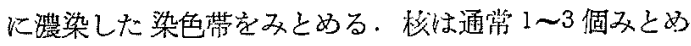
られるが，2秋のものが最も多数である。旮れらの維胸 に混つてしばしば散在性に緗胞体が浸染し，著しく小さ

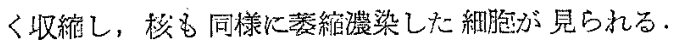
Nissl 染色では明暗二種の細舵をみとめる. Nissl 小体 は細胞周辺に多く，いわゆる園边染色带を形成している 
功，核周国染色带は見られない，周辺染色带より中心部 飞到る間は微細顆柆が密洒配列しているもの，また粗大 剩粒の混在しているものも見られるが，中には周辺染色 带の不規則なるの，Nissl 顆粒の一部集合，または尔除 しいわいる Chromatolyse と鑑別困蜼なものもみとる られる。校性核膜にて㱏蔽われ，中に1〜3個の核小体が

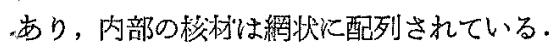

腹腔神経節 細胞も上頸神経節 細胞とほ亡゙.同様である が，細䏲の形がや」不規剘であり，菜縮濃染しているる のがや〉多数み上められる.

\section{III 神経節細胞の变化}

1. 一般 所見

本実験においてみとめられる䄔経節細胞の所見は次の ゼとくである。

\section{a. 腫 脹}

細眍体は膨化し，被膜腔内を充たし，原形質は Eosin

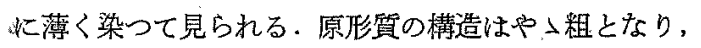

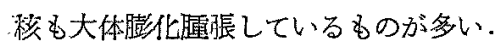

\section{“b. 萎樎}

神経節細胞の等縮が散在性にあるいは集簇性仁み的 られ，細胞体は澧染し，卡正形を呈し校も多〈は長情円 形ないし不正形を呈し，濃染している。これらの落縮し た細胞は Alcohol 標本にても中央部に少数及とるられ， 操阼群にては対照衤化比し数多く見られる。

\section{c. 空㮹形成}

多くは原形質の崩壊に伴らものが多い、空㛬は大小福 «で，数も1個より多数のもの迄色々みとめられ，部位 としては周辺性，中心性，限局性及び〉まん性と各稉あ ク，中には多数の大空胞により原形質の大部分がしぬら れているむのるみとめられる。

\section{d. 崩䁲}

初期の変化に执いては細脃原形貿は粗となり，網状を 呈するようになる。ささらに進むと原形貿は周辺部なたは 中心部から漸次崩壞像を呈してくる，周辽性のものは， 細胞膜が破壤され周㲽上り顆柆状になつてくる、著明な ものは原形質は洼とんど消失し，痕跡を残すのみにな

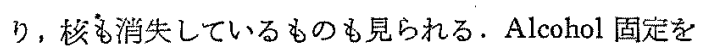
したものでは浸㵎の速かな周辺部の細渔には対照群に枋 れても軽度に崩壊がつととめられる。

\section{e. Niss1 顆粒の変化}

軽度の变化は Nissl 顆粒の配列が乱れ，一部濃染の傾 淌を呈してくる、ついで染色質の崩懐，すなわら Chromatolyse をきたす。こえれには中心性，限局性，周辺性，
びまえ性などがあり，この部の顆柆は消失し，また一部 飞集筷し，この部は非常に漉染する上うになる。最も多 く見られるのは限局性及び中心性 Chromatolyse であ る。

f. 核の変化

核は正常のむのは円形及び管円形を呈しているが，細 胞体の䭪脹に伴い棪の腄張をきたするのも数多く，また 菱縮濃染しているものも多数みとめられる。また阶艺 失い，不正形を呈するすの，周辺が凹山を呈するすの，

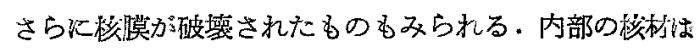
網状構造を失い，一部に集簇したもの，消失したものな

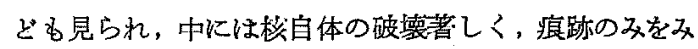
とめるもの，稀には消失したものる見られる、核の偏位 る一部のものにはかなり著しくみとめられる。

2. 各群神経節細胞の所見

a. 第】群 (2〜3時間群)

第 I 洋神経節細胞には上頸, 腹腔両神経節細胞已。儿 ほとえど変化をみとめないか，または軽度の変化をみと ふるにすぎない，埂脹は全神経節細胞にわたつてみとめ

第 2 表 第] 群交感神経節細胞所見

\begin{tabular}{|c|c|c|c|c|c|c|c|}
\hline 動物 & 部位 & 隀脹 & 萎絠 & 空胞 & 崩壊 & 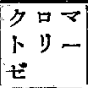 & $\begin{array}{l}\text { 核の } \\
\text { 変化 }\end{array}$ \\
\hline 19 & 上 & - & + & + & - & & - \\
\hline 20 & 上 & - & - & + & + & & - \\
\hline 21$\}$ & 卡 & $=$ & \pm & + & $\bar{t}$ & & $\overline{-}$ \\
\hline 22$\}$ & 点 & $\overline{-}$ & $\overline{-}$ & $+\dot{+}$ & + & & - \\
\hline 26 & 腹 & - & + & - & + & & - \\
\hline 27 & 上 & - & - & + & + & & - \\
\hline 28\{ & 点 & $\overline{-}$ & $\bar{z}$ & + & + & & - \\
\hline 29 & 上 & - & + & - & - & & - \\
\hline 30 & 上 & - & - & + & + & & - \\
\hline 31 & 上 & - & + & - & + & & + \\
\hline 32 & 上 & - & + & + & + & & - \\
\hline 33 & 1. & - & + & - & - & & - \\
\hline 34 & . & - & + & + & - & & - \\
\hline 35 & 上 & - & + & + & - & & - \\
\hline 43 & 上 & - & + & + & + & + & - \\
\hline 44 & 上 & - & - & + & - & + & - \\
\hline 48 & 上 & - & - & + & - & + & - \\
\hline 49 & 上 & - & - & + & - & + & - \\
\hline 50 & 上 & - & - & - & - & - & - \\
\hline
\end{tabular}


られない. 萎繀は No. 19, 21, 29, 31, 32, 33, 34, 35, 43 の各上頸節及び No. 26 腹腔節細脃にはいずれる怪度に みとめられ，その他の動物の上頸節及び䧗腔節細胞には 双とめられない，その中で No. 21，32，34 上頸節細脱 の炭縮はとくに軽度である、空胞形成は 5 例老除いて他 の全ての神膯節にみとめられるが，いずれる軽度の小空 胑形成である。その中 No. 21 上頸節は周辺性空胞であ り，その他のものはいずれる原形質内空涪形成である. 源形質の崩垶は過半数の袖経節にみとめられ，これらは いすれれも原形質の構造がや〉粗となつた程度のものが多 く，明らかな崩蔆と思われるるのは胃られない、すなわ ๖それらは No. 20,22, 27, 28,30,31，32,43 の各上頸 節及び No. 21，22，26，28 の各腹腔節細脑にみとわられ る. 本群で Nissl 染色にて観察したものは No.43，44， 48，49，50 の各上頸節であるが，この中 No.50 上頸節 細胞以外のものはいずれも軽度の Chromatolyseをみ とめる。これらはいずれる中心性及び限局性のものであ る.核は No.31 上頸節細胞にてはや小萎縮変形をみと めるが，との他の神経節にて何等の変化をみとめない， 以上の所見を第 2 表见示す

b. 第】群 ( 5 日羭)

第】群神経節細胞は一般に第】群に較ベてかなり望し い变化がみとめられる. 国脹は No. 401 上頚節, No. 413 上頸節, 腹腔節, No. 416 上頸節, No. 420 腹腔節, No. 423 腹腔節には轻度に，また No. 411 腹腔節には 中等度に，さらに No. 425 腹腔節にはや」著明にみと められる. 萎縮性約 $3 / 4$ の神経節においてみとめられ る.すなわら No. 401 上頸節，No. 402 上頸節及び No. 411 腹腔節にては軽度の索縮像を，No. 413 上頸 節は一部の細肥に菱維を胃，No. 416 上頸節にて限局性 にNo. 419 上頸節にてはや〉多数の細胞に沶縮を, No. 420 上頸節，腹腔節にては限局性に軽度の萎縮像を，

No. 421 腹腔節にてはごく少数の細胞に，No. 423 上頸 節にては俥度の，腹腔節にては限局性に軽度に，No. 425 上頸館にては少数の細胞に萎縮像をみとめ，また No. 411 上钼節には中等度の等縮像を, さbK No. 401 腹膑節，No. 421 上頸節にはかなり治度の萎縮像を子 とめる. 聓胞形成はほとえどの种経斯にみとめられる。 すなわち No. 402, 416, 420, 423 の各上頸節及び No.

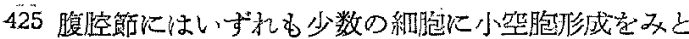
める.また No. 413 腹腔節には大小種々の空胞を少数の 細胞に見，さらに No. $40 \mathrm{l}$ 上頸酦，腹腔節，No. 411 上頸節, 腹腔節, No. 413 上頸籍, No. 419 上頸節, 腹
腔節, No. 421 腹腔䬦, No. 423 腹腔飾, No. 425 上 頸節にはいずれるかなり著しい空胞形成をみとめ，No． 420 腹腔節には多数の小空胞之少数の大空胞形成をみと

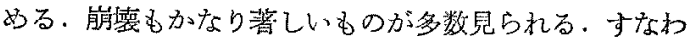
b No. 401 上頸節，No. 411 上项節，No. 420 腹腔幯，

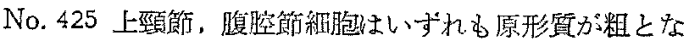
り網状に見える.No. 401 腹腔節，No. 402 上頸節，腹 腔節, No. 413 腹腔毁, No.416 腹腔節, No. 419 上䫓 節細胞にはいずれも嚜かな原形貿崩填がみとわられ，ま た No. 420 上頸節，No. 423 上頚節は周辺上り軽度の 崩譬を始好て扣り，さらに No. 411 腹腔節，No. 413

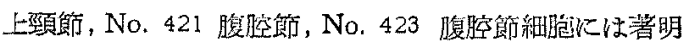

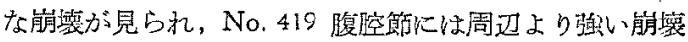
をみとめる.Nissl 染色にて見るとNo.416 腹腔節細胞

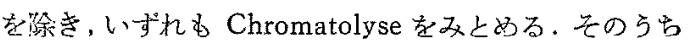
No. 419 上頸節, No. 420 腹腔節, No. 421 腹腔節,

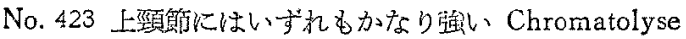

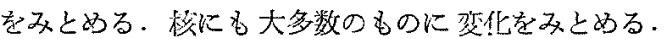

No. 401 上頸節にては㪕い変形を，腹腔節にては策縮 孛, No. 402 上頸節は少数の名のに获縮を, No. 411 上

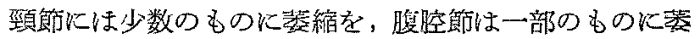
縮濃染を，No. 413 上頸節，腹膑䬣には一部少数のもの に菱縮を，No. 419 上頸節は一部のものに变形及び萎縮

第 3 表 第 II 群交感神経節細胞所見

\begin{tabular}{|c|c|c|c|c|c|c|c|}
\hline $\begin{array}{l}\text { 動物 } \\
\text { 番量学 }\end{array}$ & 部位 & 腄脤 & 薮䅯 & 空胞 & 前壊 & $\begin{array}{ll}9 & 0 \\
1 & 9 \\
i & 1\end{array}$ & $\begin{array}{l}\text { 核の } \\
\text { 变化 }\end{array}$ \\
\hline 401\{ & $\frac{5}{\text { 腹 }}$ & + & $t$ & $H$ & + & + & + \\
\hline 402 & 吉 & - & 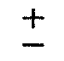 & \pm & + & + & \pm \\
\hline 411$\}$ & 卡 & $\overline{+}$ & + & $\begin{array}{l}H \\
H\end{array}$ & + & + & + \\
\hline 413\{ & 卡 & + & \pm & $\begin{array}{l}+ \\
+\end{array}$ & $\begin{array}{l}H \\
+\end{array}$ & + & + \\
\hline 416 & 占 & \pm & \pm & \pm & $\overline{+}$ & \pm & $\overline{-}$ \\
\hline 419\{ & $\frac{1}{10}$ & - & 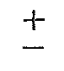 & $\begin{array}{l}H \\
H\end{array}$ & $\stackrel{+}{+t}$ & $H$ & + \\
\hline 420$\}$ & $\frac{1}{\text { 腹 }}$ & $\overline{+}$ & + & + & + & + & $\stackrel{+}{+}$ \\
\hline 421\{ & 傹 & - & $\begin{array}{l}+1 \\
+\end{array}$ & $\bar{H}$ & $\bar{H}$ & + & + \\
\hline 423\{ & $\frac{1}{\text { 腹 }}$ & $\overline{+}$ & + & $\frac{+}{H}$ & $\frac{1}{+}$ & $H$ & + \\
\hline 425\{ & $\underset{1}{\stackrel{上}{上}}$ & $\bar{H}$ & \pm & $\begin{array}{l}H \\
+\end{array}$ & $\begin{array}{l}+ \\
+\end{array}$ & + & + \\
\hline
\end{tabular}


を，腹腔節には萎縮濃染しているものを，No. 420 上頸 節, 腹腔節には埾度の萎縮震染を, No. 421 上頸節, 腹 腔節，No. 423 上頸節，腹腔節にはいずれも軽度の萎縮 をまた No. 425 上頸節には変形濃染しているるのを， 腹腔節にはや入蓄明に萎縮源染しているものと一部軽度 に崩壊しているものとをみとめる，以上の所見を総括し て第 3 表沶す

\section{c. 第四群 (10日群)}

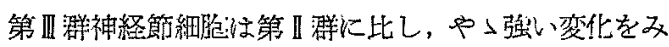
とめる.腄掁は約 $3 / 4$ の神経節に見られる。すなから No. 317 腹腔節, No. 320 上頸節, 腹腔節注は軽度の 腫掁が見られ，No. 331 上頸節には一部の細胞さ限局性 飞腫脤がみられる。 No. 301 腹腔節, No. 305 上頸節, 腹腔節, No. 308 上頸節, 腹腔節, No. 313 腹腔節, No. 322 腹腔節，No. 331 腹腔節にはいずれもかなり

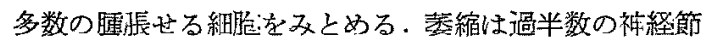
にみとめられる. 寸なわち No. 317 上頸節, No. 320 上頸節, No. 324 上形節, No. 331 上頸節, 腹腔節, No. 334 上頸節には少数の細胞に散在性に軽度の萎縮を みとめる. No. 301 上頸節, No. 324 䧗腔節細肬柿一部 飞限局性に䔀縮をみとめる. No. 313 上頸節, No. 322 上頸節，No. 334 腹腔節細胞火はかなり暏明な萎縮をみ る、空胞形成はほとんどずての神経節にみとめられ る.その大部分は細胞体内に少数の小空腊形成をみ上ぬ るむのであるが，No. 313 腹腔節細㺼には周辺性に大小

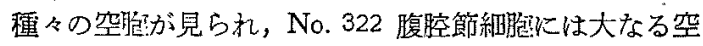
肥が多数みとめられ，中には空胞のために原形質がほと んど破壊されているものもあり，さらに No. 331 腹腔

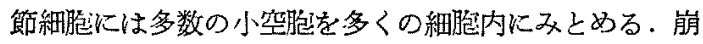
壊も活とんどすべての神経節にみとめられる。すなわら No. 301 上頸節細航は原形質網状となり崩潈の初期像を 示している，腹腔節細胞は周辺性崩堎がかなり著明に見 られる. No. 305 上頸節細胞は顆粒状に崩壤して抏り, 腹腔節細胞愉状に粗な観を呈している. No. 308 上頸 節細脃原形質は周辺部が軽度に崩壤，腹腔節細胞原形質 はかなり著明に網状に崩壊している，No. 313 上頸節は 原形質は網状に崩瀤しておりり，腹腔節細胞原形質は崩㯖 が非常に著しく，原形質の大部分を失つているるのもあ る. No. 317 上頸節細胞には軽度の崩偯変形を, 腹腔節 細脆には網状崩淁を呈するるのを少数みとるる. No. 320 腹腔節細胞には崩塙初期像を呈するもの少数を見， No. 322 上頸節，腹腔節ともに相当著しい崩壊像をみと 凶る. No. 324 上頸節, No. 331 上頸節, No. 334 上
頸節，腹腔節はいずれも㪕度の崩壊をみとめるが，No。 324 腹腔節, No. 331 腹腔節には軽度限局性崩壞像が見 られる. Chromatolyse は Nissl 染色にて䚔察した神 経節に全てみとめられるが，その中 No. 313 腹腔節， No. 320 腹腔節, No. 322 上頸節, 䧗腔節, No. 324 腹腔節，No. 331 腹腔節にはいずれもかなり著明なる のを見るが，その他のものにはいずれる軽度の中心性 Chromatolyse をみとめる.核にもほとんぞのものに変 化をみとめる.すなわち No. 301 上頸節, 腹腔節, No. 305 上頸節, No. 308 上頸節にはいずれも画掁と輆械の 乱れが軽度にみとめられ，No.322 上頸節は核材の配列 が乱れており，No. 313 腹腔節，No. 322 腹腔節には 腫脹と核材の乱れがかなり著しく，また No. 305 腹胵 節, No. 308 腹腔節, No. 320 腹腔節, No. 324 腹腔 節, No. 331 上形節, 腹腔節, No. 334 上頸節, 腹腔 節にはいずれも菨縮率形が軽度に見られる．以上の所見 を總合すると第４表の珓くになる。

第 4 表 第囵群交感神経節細胞所見

\begin{tabular}{|c|c|c|c|c|c|c|c|}
\hline $\begin{array}{l}\text { 動物 } \\
\text { 番亲 }\end{array}$ & 部位 & 腫脹 & “萎䊒 & 空胞 & 崩壞 & $\left|\begin{array}{lll}9 & 0 & -1 \\
1 & 1 & -1 \\
z^{3} & -1\end{array}\right|$ & $\begin{array}{l}\text { 榜の } \\
\text { 変化 }\end{array}$ \\
\hline 301$\}$ & 卡 & $\bar{H}$ & \pm & + & $\stackrel{+}{+}$ & + & + \\
\hline 305\{ & 卡 & $H$ & $\overline{-}$ & + & + & + & + \\
\hline 308 & $\frac{上}{\text { 脜 }}$ & $H$ & $\overline{-}$ & + & + & + & + \\
\hline 313 & 卡 & $\bar{H}$ & H & + & $\stackrel{+}{\mathrm{H}}$ & $H$ & $\bar{H}$ \\
\hline 317 & 攴 & $\overrightarrow{+}$ & \pm & + & $\stackrel{+}{+}$ & + & $\underline{-}$ \\
\hline 320 & 点 & + & \pm & $\bar{t}$ & $\bar{t}$ & $\stackrel{+}{H}$ & $\bar{t}$ \\
\hline 322 & 卢 & $\bar{H}$ & H & $\stackrel{+}{H}$ & H & $H$ & $\stackrel{+}{H}$ \\
\hline 324 & 卡 & $\overline{-}$ & + & + & + & $\stackrel{+}{H}$ & $\bar{t}$ \\
\hline 331 & 腹 & $\stackrel{+}{H}$ & $\stackrel{+}{+}$ & $\stackrel{+}{H}$ & + & $\stackrel{+}{H}$ & + \\
\hline 334 & 星 & $\overline{-}$ & + & + & + & + & + \\
\hline
\end{tabular}

\section{d. 第N N澼(20日澼)}

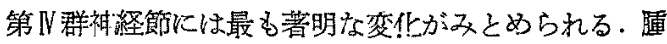
脹は約半数の神経節にみとめられる.すなわち No. 109 腹腔節，No. 116 腹腔節細苞には軽度の婳脹がびまん性 にみとめられ，No. 101 上頸節，No. 109 上頸節細鸠 にはかなり著しい圗脤が見られるたた No. 117 上頸節， 
No. 124 上頸節細胞には軽い腫脹が限局性に，さらに No. 117 腹腔節，No. 121 上頸節細胞には等明な蹗脹 が限局性にみとめられる。萎縮は全例にわたつてみとめ られる. No. 115 䧗腔節, No. 121 上頸節, No. 124 腹腔節には軽度の荌縮像を久とめ，またをの他の全部に かなり著しい萎縮像をみとめるか゚，その中 No. 101 腹 腔節, No. 117 腹腔節, No. 122 上頸節, No. 124 上 頸節細胞には限局性に萎縮をみとめる，架胞形成もはと えど全例にみとめられるが，No. 103 腹腔節，No. 109 上頸節, 腹腔節, No. 116 腹腔節, No. 117 腹柱節, No. 121 腹腔節，No. 122 上頸節にはいずれる一部の 細胞に小空胞をみとめ，また No. 101 上頸節，腹膑節， No. 113 上頸節, No. 117 上頸節, No. 119 上頸節, 腹腔節，No. 121 上頸節，No. 123 上頸節，No. 124 上頸節，腹腔節細胞にはいずれるかなり著しい空胞形成 をみとるる.さらに No. 115 腹膑節紐胞には大小種々の 架胞が非常に著明に見られ，そのために原形質のほとん ど見られないるのもみとられる。原形質の崩壊も全例 に柇てみとめられる.すねわ占 No. 109 上頸節， No. 116 上頸節, 腹腔節, No. 117 腹腔節, No. 119 上頸節，No. 123 上頸節，No. 124 腹腔節にはいすすれ る軽度の崩壊がみとめられ，この中No１19 上頸節に 恦周部にとくに著しい，また No. 101 上頸節，腹腔 節, No. 103 上頸節, 腹腔節, No. 109 腹腔節, No. 113 上頸節, No. 117 上頸節, No. 119 腹腔節, No. 121 上頸節，腹腔節，No. 122 上頸節，No. 124 上頸 節にはいずれる著明な崩壊をみとめ，さらに No. 115 腹腔節はとくに著明な崩壊をみ，原形貿のほとんと゚見ら れないるの存する. Chromatolyse は Nissl 染色を 袺どこせる全例に見られ，No. 103 上頸節，腹腔節， No. 119 上頸節には䓩度の，No. 116 腹腔虒，No. 117 上頸節，No. 121 腹腔節，No. 123 上頸節にはいずれ

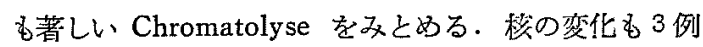
を除いたものにみとめられる。すなわち No、101 上頸 節は散在性に蘶縮を軽度に，腹腔節には深縮，崩萝，消 失を著明に，No. 109 上頸節は軽度の崩壊を，No. 113 上頸筑はかなりの萎縮及び腫脹を，No. 115 腹腔節には

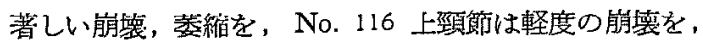
腹腔節は核材の軽度の乱れを，No. 117 上頸節は軽度の 崩㯖を、腹腔節はがりの萎縮变形をみとよ，No. 119 上頸節は軽度に玟材の乱机を，腹腔節はかなりの萎縮及 び崩壊を，No. 121 上頸節は著明な崩壊を，腹腔毁には 軽度の崩壊を，また No. 122，123 上頸節には軽い菱縮
第 5 表 的 $\mathrm{V}$ 辝交感神綎節絧胞所見

\begin{tabular}{|c|c|c|c|c|c|c|c|}
\hline $\begin{array}{l}\text { 婳物 } \\
\text { 番啰 }\end{array}$ & 部位 & 隀脹 & 菱維 & 空胞 & 筋墒 & $\begin{array}{lll}y & \nabla \\
1 & 1 & \\
2 & \\
\end{array}$ & $\begin{array}{l}\text { 核の } \\
\text { 变化 }\end{array}$ \\
\hline 101\{ & 卡 & H & H & $H$ & $H$ & & + \\
\hline 103\{ & 卡 & $\overline{-}$ & $H$ & $\bar{t}$ & $H$ & + & $\overline{-}$ \\
\hline 109 & 卡 & $\begin{array}{l}H \\
+\end{array}$ & H & + & $\stackrel{+}{+}$ & & \pm \\
\hline 113 & 上 & - & $H$ & $H$ & $H$ & & $H$ \\
\hline 115 & 腹 & - & + & H & Ht & & $H$ \\
\hline 116 & $\frac{\text { 上 }}{\text { 腹 }}$ & $\bar{t}$ & H & $\overline{+}$ & + & $H$ & + \\
\hline 117 & 卡 & + & $H$ & $\begin{array}{l}+ \\
+\end{array}$ & $\stackrel{+}{+}$ & $H$ & + \\
\hline 119 & 旗 & - & $H$ & $H$ & $\stackrel{+}{+}$ & + & + \\
\hline 121\{ & 上 & H & + & +4 & $+H$ & $H$ & $\begin{array}{l}+ \\
+\end{array}$ \\
\hline 122 & 上 & - & $H$ & + & $H$ & & + \\
\hline 123 & 上 & - & $t$ & $H$ & + & $H$ & + \\
\hline 124 & $\frac{上}{\text { 腹 }}$ & \pm & $\begin{array}{l}+ \\
+\end{array}$ & H & + & & + \\
\hline
\end{tabular}

を,さらに No. 124 上頸節細胞には軽い、菱縮, 崩壊を, 腹腔節細狍には軽度の崩壊をみとめる．以上第 $\mathbb{N}$ 所 見を第 5 表に示す

\section{N.内藏々器の所見}

1. 肺臓：腩胞壁はほとえど 正常なるの，無気肺 状のbの, 肺気㙞の像を呈するものなど種々の所胃が見 られるが，浮盾状に肥厚しているものが多く，とくに第

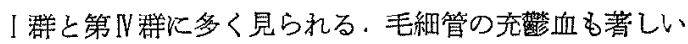
むのが多いが肺胞腔内に出血しているものは第り群に 1 例見られるにすぎないしかし間質円形絓胞痩潤はかな り著明である。小気管支壁，毛細気管支壁は各群に朊い て肥寔しているものが見られ，また内腔に Eosin に淡

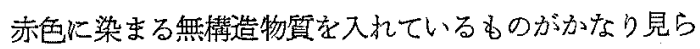
れる・この4臂を比輘して見ると，各群間にはあまり著 明な差はみとめられないが第】群にて一盘著しい変化が みとめられる。

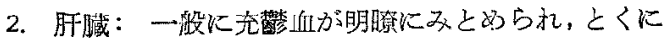
中心静脈，Glison 氏鞘，小藮閏毛細管にかなり著明に 見られる、肝細胞は篓維しているものはほとんど見られ ないが，原形留の变性をみとめるものはかなりあり，中 には空胞形成の見られるむのもある。校にはほとれど変 化をみとめない，文星状細胞の变化や，間質内円形細胞 浸潤は見られない，各群間の変化では全般的に見て第I 
第 6 表 肺 臓 $の$ 変 化

\begin{tabular}{|c|c|c|c|c|c|c|c|c|c|c|c|c|c|c|c|c|c|c|}
\hline 科 & & 第 & & & & & & $\mathbb{U}$ & & 第 & $\mathbb{1}$ & & & 第 & I & V & W & \\
\hline 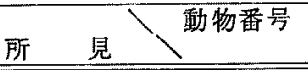 & 19 & 20 & 22 & $26 ;$ & 29 & 41 & 401 & 402 & 411 & 301 & 305 & 308 & 101 & 103 & 109 & 115 & 116 & \\
\hline 気 管 支 壁 是 & & & & & & - & & & & + & T & + & & & - & - & + & \\
\hline 気管支内腔禩常 & + & + & + & + & + & + & + & + & - & + & + & + & + & + & + & + & + & - \\
\hline 肺 胞 壁 異 常 & $H$ & - & - & H & $H$ & $t$ & 1 & + & - & H & + & + & $t$ & & H & + & H & \\
\hline 充 & $H$ & $H$ & $H$ & H & $H$ & H & H & t & - & $H$ & $H$ & H & H & 4 & + & + & + & - \\
\hline 出 & - & - & 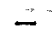 & - & - & - & - & 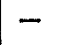 & - & 一 & - & - & + & - & - & - & - & - \\
\hline 棌 & $H$ & - & - & $H$ & H & $H$ & H & t & - & $H$ & + & + & $H$ & + & $H$ & + & + & - \\
\hline 肺胞隔壁内円形細胞浸潤 & + & + & + & $H$ & + & $H$ & $H$ & + & + & + & $H$ & + & + & + & +1 & - & - & \\
\hline
\end{tabular}

第 7 表旰臟 $の$ 変. 化

\begin{tabular}{|c|c|c|c|c|c|c|c|c|c|c|c|c|c|c|c|c|c|c|}
\hline 群 & & 第 & & & 群 & & 第 & I & & 第 & III & & & 第 & 1 & V & 群 & \\
\hline 見 動 & 19 & 20 & 22 & 26 & 29 & 41 & 401 & 402 & 411 & 301 & 305 & 308 & 101 & 103 & 109 & 115 & 116 & 119 \\
\hline 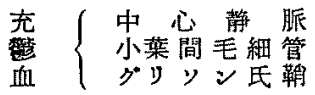 & $\begin{array}{l}+ \\
+ \\
+\end{array}$ & $\begin{array}{l}+ \\
+ \\
+\end{array}$ & $\begin{array}{l}+ \\
+ \\
+\end{array}$ & \pm & $\begin{array}{l}+ \\
+ \\
+\end{array}$ & $\begin{array}{l}\bar{t} \\
+\end{array}$ & $\stackrel{+}{ \pm}$ & $\begin{array}{l}+ \\
\pm \\
-\end{array}$ & $\bar{t}$ & $\frac{ \pm}{+}$ & \pm & $\begin{array}{l}+ \\
+ \\
+\end{array}$ & $\frac{H}{t}$ & $\frac{ \pm}{-}$ & $\begin{array}{l}+ \\
+ \\
+\end{array}$ & $\begin{array}{l}+ \\
+ \\
+\end{array}$ & $\frac{1}{-}$ & - \\
\hline 縮 & - & - & - & - & - & - & - & - & - & - & - & - & - & - & - & - & - & - \\
\hline 原 形翼 変性 & + & $\stackrel{H}{+}$ & $H$ & $H$ & \pm & $\bar{z}$ & + & $\underline{t}$ & - & \pm & \pm & - & $=$ & \pm & \pm & $\bar{t}$ & - & \pm \\
\hline 胞 & - & - & - & + & - & - & - & - & - & - & + & - & - & - & - & - & - & - \\
\hline 壊 & - & - & - & - & - & - & - & - & - & - & - & - & - & - & - & - & - & - \\
\hline 星 細 胞 変 化 & - & - & - & - & - & - & - & 一 & - & - & - & - & - & - & - & - & - & - \\
\hline 間質 円形細胞 浸潤 & - & - & - & - & - & - & - & - & - & - & - & - & - & - & - & - & - & - \\
\hline
\end{tabular}

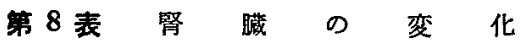

\begin{tabular}{|c|c|c|c|c|c|c|c|c|c|c|c|c|c|c|c|c|c|c|c|c|c|}
\hline \multicolumn{4}{|c|}{ 群 } & \multicolumn{2}{|r|}{ 第 } & \multicolumn{2}{|c|}{ I } & \multicolumn{2}{|l|}{ 群 } & \multicolumn{3}{|c|}{ 第 $\mathbb{I}$ 群 } & \multicolumn{3}{|c|}{ 第 III 群 } & \multicolumn{3}{|c|}{ 第 } & IV & \multicolumn{2}{|l|}{ 群 } \\
\hline 所 & 見 & 動物 & & 19 & 20 & 22 & 26 & 29 & 41 & 401 & 402 & 411 & 301 & 305 & 308 & 101 & 103 & 109 & 115 & 116 & 119 \\
\hline 充血 & $\begin{array}{l}\text { 采 } \\
\text { 細 }\end{array}$ & 尿 & $\begin{array}{l}\text { 体 } \\
\text { 部 }\end{array}$ & + & $H$ & $H$ & + & $\begin{array}{l}H \\
+\end{array}$ & + & $\begin{array}{l}+ \\
+\end{array}$ & \pm & + & + & $\begin{array}{l}+ \\
+\end{array}$ & \pm & \pm & $\begin{array}{l}+ \\
+\end{array}$ & + & $\begin{array}{l}+ \\
+\end{array}$ & + & \pm \\
\hline $\begin{array}{l}\text { 出 } \\
\text { 血 }\end{array}$ & $\begin{array}{l}\text { 系 } \\
\text { 細 }\end{array}$ & 疗 & $\begin{array}{l}\text { 体 } \\
\text { 部 }\end{array}$ & $=$ & $\overline{-}$ & $\overline{-}$ & $\overline{-}$ & $=$ & $\bar{z}$ & $=$ & 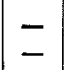 & $=$ & $=$ & $=$ & $\bar{z}$ & $=$ & $=$ & $=$ & $z$ & $=$ & $\overline{-}$ \\
\hline $\begin{array}{l}\text { 系 } \\
\text { 球 } \\
\text { 体 }\end{array}$ & 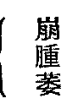 & & $\begin{array}{l}\text { 䁾 } \\
\text { 繀 }\end{array}$ & $\bar{t}$ & $\stackrel{+}{+}$ & $\dot{+}$ & \pm & $\bar{z}$ & $\bar{z}$ & \pm & $\begin{array}{l}+ \\
+ \\
+\end{array}$ & $=$ & \pm & $=$ & $\bar{z}$ & \pm & $\frac{-}{+}$ & $\begin{array}{l}- \\
+ \\
+\end{array}$ & $\bar{z}$ & $\frac{7}{+}$ & $\bar{z}$ \\
\hline $\begin{array}{l}\text { 細 } \\
\text { 瓜 } \\
\text { 管 }\end{array}$ & $\begin{array}{l}\text { 上 } \\
\text { 上 } \\
\text { 上 }\end{array}$ & 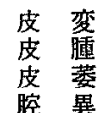 & $\begin{array}{l}\text { 性 } \\
\text { 縟 } \\
\text { 嘗 }\end{array}$ & $\frac{t}{t}$ & $\stackrel{+}{+}$ & $\begin{array}{l}+ \\
+ \\
+ \\
+\end{array}$ & $\stackrel{+}{+}$ & $\begin{array}{l}+ \\
+ \\
+\end{array}$ & $\frac{+}{+}$ & $\underline{\bar{H}}$ & $\begin{array}{l}+ \\
\pm \\
-\end{array}$ & $\frac{t}{ \pm}$ & $\begin{array}{l}+ \\
+ \\
+\end{array}$ & 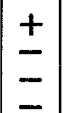 & $\frac{ \pm}{ \pm}$ & $\frac{ \pm}{t}$ & \pm & \pm & $\begin{array}{l}+ \\
\pm \\
\pm\end{array}$ & $\begin{array}{l}+ \\
\pm \\
+\end{array}$ & $\begin{array}{l}+ \\
+\end{array}$ \\
\hline & 今 形 & 細胞 & & - & - & - & - & - & - & - & - & - & - & - & - & - & - & - & - & - & - \\
\hline
\end{tabular}


第 9 表 副督 の 変 化

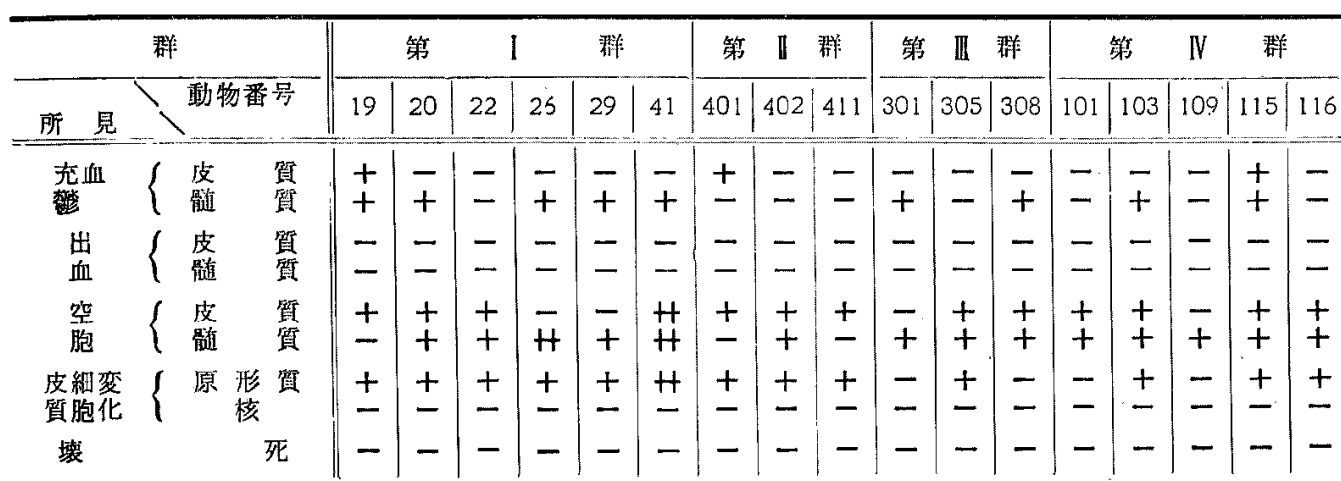

絮が変化强く，その他の洋には差は少ない，

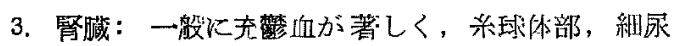
管毛細管にとくに强くみとめら机る。系球体は婳人して いるむの，莠縮しているるのが混在してみとめられ，少 数傰壊が見られる，細尿管上皮は㬝掁しているものが 多く，また变性しているものも見られる。細㞗管内腔に は Eosin に赤染する円柱物質を入れているるのがある が，しかし出血性変化や閪質の円形細胞浸潤はみとめら

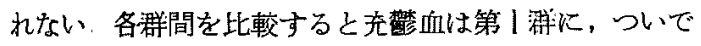
第以澼に强く見られるが，その他の変化には著しい差を 熘的ない。

4. 副緊：全般的にあまり蚛い变仰は見られないが，

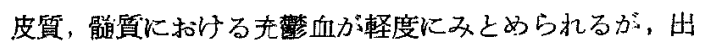
血は全例に見られない，細胞変性は第 I群にや〉强くみ

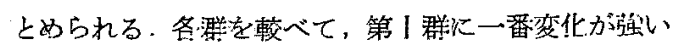

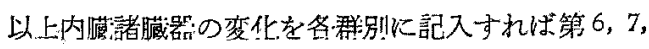
8, 9 表の如くである.

\section{綕括並びに考按}

正常な神経細胞の組䋨的研究に関しては Cajor, Müller ${ }^{11)}$, Stöhr 16), Herzog 5), 大沼 ${ }^{33)}$ らにより数多くの 啈告がなされ，その钽細構造が追求されてきた。ほた州

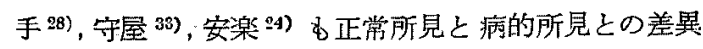
について記戴しているが，その汪とんどが人間及び冢雨 のものであつて，モルモッに関しては見るべきるのが ない、被経節細脆にしばしばみとめられる細胞体や核の 萎縮硬仆に関して，大沼 ${ }^{38)}$ はこの密化出 Formalin 固 定の封のみにみとめられ，Alcohol 固定標本にてはみと められないために人工産物であると述べているが Abrikossoff ${ }^{11}$ ，Mogilnizcky ${ }^{10)}$ らはこれに反して病的細胞

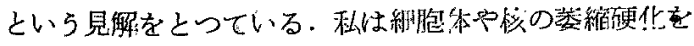
Alcohọl 固定にても若十みとめ，から操作群にてこの変
化を多数みとめるが，その差悇り著朋でなく，病的

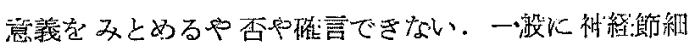
胞の核数に関して Müller ${ }^{11)}$ は動物では 2 核性のもの がら்つうであり，大沼 ${ }^{38)}$ もルモットでは2核性のる のと単晐性のbのとほ心゙相半ばし、3核ないし多核のむ のは人間に比べて、甚だじしばであるといつている。

Guye, Remark は3核をみとめ, Schwalbe は2核の ものは稀としているが，Terplan 㤌 2 核が多いといつて

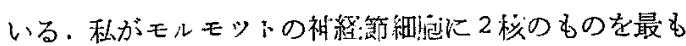
多数みと好たこともこれらの所見と同様と考之られる。

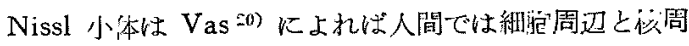

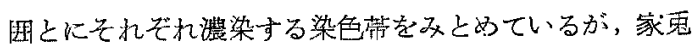
で注移周囲染色带はみとめられないとのべ，井手８）む 同様な所見を報告しこれれ替意を表している。モルモ ッ:においては家雨と同样に細胞周囲染色帯のみ〉とめ られる。

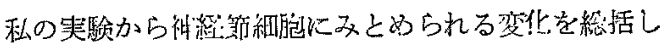
てながめてみると Croton 油注射 2〜3 時間後である第 I群に括ける神経節細胞の所見は，いずれも㴙赈，萎 縮, 小空胞変性, Chromatolyse などを僅かにみとめる にすぎず，これらを対棐群と比較してみて明らかな差巽

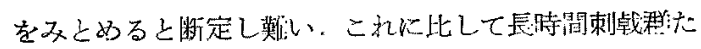

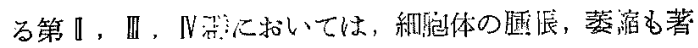
しく，かつ空胞形成，崩摆もはるかに高度であり，核に もかなりの変化をみとめるるのが多数見られる，長時旧 㴫では一般に観察期間が恣くなるにつれて变化の程度も

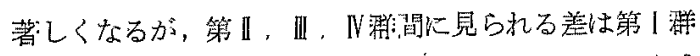

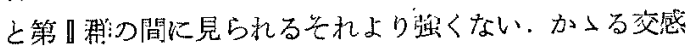

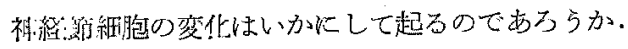

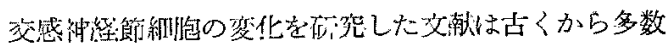

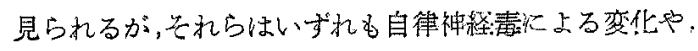


各栕の疾患の際に見られるものを観察したものが多い． これらを简単に考察すると。

Hedinger, 高䌾 ${ }^{53)}$, 井手28) は Adrenalin を注射し た際の交感神経系統の変化をしらべ，高楠53)，中島は Pilocarpinを，ぬた井手 28)は Cocain を注射した時の 変化を, さらに Herzog, 高楠54) は Nicotin に上る变

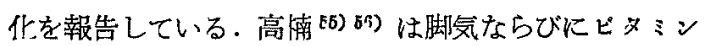
$\mathbf{B}_{1}$ 欠乏症及び沜白米病に括ける神経節細胞の変化を， Trousseau, Petor, Siemrling, Grieufield, Herzel, Möbius, Graupner, Ehrlich, Virchow, Horand,

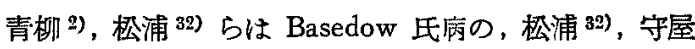
33)は甲状腺物質を投与せる動物の上頸節細胞の变化を， Fos, Ljubinoff, van Gechuchter, Daddy \& Nelis, Chachina, Slomma, Ywanowsky, Moglinizcky, Laignal \& Lavastine, Abrikossoff 1), Herzog 6) Б任伝染 病の, 安楽 ${ }^{24)}$, Terplan 18), Wohlwill 22), 小出に( , 浅 見 ${ }^{23)}$ ，大沼 ${ }^{33)}$ らは各穞突患の際の変化を，またVas は通電した際の交感神経節細胞の変化を調べ報告してい るが，いずれる細胞の萎縮, 腄掁, 崩壊, 变性, Chromatolyse，細胞浸潤，核の変化などについて記載してい る.以上の研究はすべて楽品や疾病等の全身的変化の際 の影饗が交感神経系にいかに及ぼされるかる就究したむ のであるが，私は先人と違ら立場に批いて，先に飯田の 報告した口唇克の刺㦸が全身に及ぼす経路として交感神 経節細胞にいかなる変化を発来するかを検討してみた． すなわち Croton 油という吸収されることが少なく， 局所の战刺に適した物質を用いて，口唇と腹部皮下に注 射し， $0.1 \mathrm{cc}$ の量では口唇に注射した時にのみ Shock 様症状を発現せしめえた飯田 ${ }^{27)}$ の実験，さらに Shock 時にみられた全身蔵器の変化, これらはいかれして起さ れるのであろらか。これを解明する事は容易ではなく， 楎々の見解を伴らが，Reilly 現象の立場からの考察む

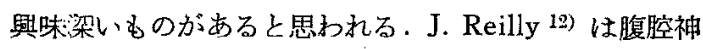
経節にチフス菌蛀菜を作用させ, 腸粘膜にチフス様变化 を起し，その原因として自律神経系の刺㦸を発表した． 私も口唇と内臓とを結ぶ経路の一つとして頸部の交感神 経系を考光，口唇に加兄られた刺战が自律神経楾維を介 して頸部神経節に，さらに腹腔神経節に波及するものと 洘觉，これら神滦䬣細胞の变化を調べて見た，勿論叶枢 との密接な関連はいうまでもない，Mallet-Guy ${ }^{8)}$ は慢 性搭蔵炎の際の腹腔被経節の变化について報告している がこれも私の考えを裹つけるものである。

Reilly が一度この見解を 発表して以来同栐の歌究が
数多くなされてきている. Marquezy. M. Ladet et P. Guathier Villars" はヂフテリア毒溸を用いで内縢々 器の変化を見，本邦では光に述べた飯田，深沢の外，佐

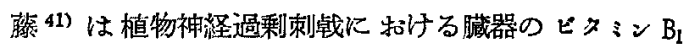
の消長について述べ，白石ら ${ }^{44)}$ は頸部植物神経を刺战 してえられた 肺臓及び 副腎の出血性病変につにて報告 しここの現象に中枢が関与すすることを示浚し，土屋・秋 庭 ${ }^{63)}$ は Reilly 現象に間脳一下垂体一副緊采の 関与の 大なることをのベ，伊藤ら ${ }^{29)}$ は頸部交感神経，内墕神 経, 腸間膜リンバ節，咽頭粘膜に Croton 油, Alcohol 注射, 電気刺㦸を加点, 内䐵の変化を報告しておう, 上 山 ${ }^{61)}$ は上頸節を Aloxan, Oxin などで刺战し，膵㺃 の变化を調べ，鈴木（啓司），高崎ら ${ }^{51)}$ は眼简下神経 をCroton 油などで刺軲し，内臓喜の变化を調く， Chlorpromazin を用いてこの阻止に成功し，その原因 として眼简下神経内に含まれる自律神経線維の刺㦸标よ

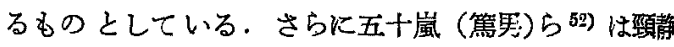

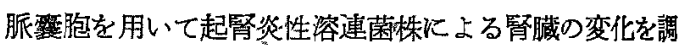
べ，鈴木（安佰），山口（英明）541 は扁桃周囲澧㴼 時に周囲自律神経刺战㳀よると思われる心電図上の変北 を報告している。

Croton 油を注射した口長より口蓋，咽頭にかけては 先に述べた飯田，またジフテリフ毒素をम唇に注射し副 腎出血を報告した長领 ${ }^{46)}$ ，さらに Adrenalin を咽頭に 注射し内臓々器の変化を調べた竹内 ${ }^{67}$ )の面究により明 らかなごとく，刺钱に対して非常に過敏性を有する特珠 な部位であることが証明されている.H. Stolze ${ }^{17)}$ はと の著“Das obere Kreuz” に执いて頸部は脳と騒幹の 連絡路にあたり，重要な血管，神経に富み，解部学上特 殊な場所であることを强調している。さらに永瀬 ${ }^{34)}$ 人扁桃で，宮部は人口蓋粘膜，倉井は人下甲介粘膜の神

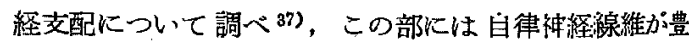
富に存在することをみとめ，微細な植物神䌊終網の染出 に成功している。杰た大野 40) は私と平行してモルモ” ト口唇に分布する神経々路と， 口唇の神経分布について 詳細な報告をなし，豊富な自律神経の存在をみとめてい る.

口唇に加えられた剌㦸が交感神経節に变化を和こすこ とについては種々の原奋が考学られる，先人の種々の報 告より考えて中毒によることも充分考えなければならな

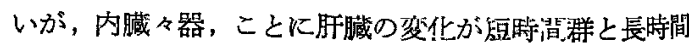
群上の間にいらじるしい差がなく，また肝細胞壊死， Kuppel 細胞の变化などがとくに强い,と思われず，Cro- 
ton 油の中書による变化は一応否定しうると思われる。 私はこの実験から自律神経系の末梢に加えられた刺㦸 が中枢に伝達され，さらに全身の変化をきたす途上種々 の伝導路を介するのであろらが，その一つの経路として 上頸神経節が重要な役割を演じ，中枢路となつて刺㦸が 全身の自律神経系に伝達され，それにより腹腔神経節に も同様な変化を見るすのと考えたい.から，内葴々器の 変化は血管柔の変化を主としていることは，この変化が 自律神経を介しておこなわれていることを明白に襄づけ ているものと思われる.すなわち末梢血管に分布する自 律神経に刺㦸か゚伝達され，充凿血，さら飞出血とい5变 化が見られるものと思ら。

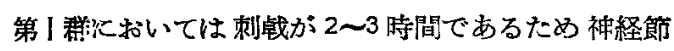
には未だ機質的変化をおこすにいたらないが，内臓諸缄 器には最も強い变化がみとめられるが，これは神経節細 胞には撒能的には强い変化が加えられ，生体の恒常性を 破り，Shock 様症状学発来するのであろう．神経節に は長特間の慢性刺㦸を加党て始めて機質的変化を招来す るのであろう．第II， III，N 動物にては稀釈した Croton 油を用いた」めた 全量としては第】群の半量 以下であつたが長時間刺战を加えたつめに前述の如き変 化を惹起したるのと考えられる。

自律神経系の刺战は以前には遠心性刺㦸のみといわれ ていたが，近来は求心性刺㦸子存する事が証明されてい る ${ }^{31)}$. 上頸神経節が迷走神释核に連絡を有することは 沖中らにより証明せられているが 25) 35) 36) 39) 45)，交感・ 副交感の両神経は互に密接な関係を保らっ今作用し，さ らに Selye の説く下垂体一副篮系もこれと相ま口, 中 枢の支配その他の因子が種々からみあつて複雑な機構の もとに外界からの剌战に対処して告体を保持し, 内部睘 境の恒常性を維持するが，生体がこれに対処できなくな つたときすなわち破綻の現われとして Shock 様症状 の発現えと向らものと思われる。

鈴木 (安恒) 5 48) は手術時発生する Shock の推定 原因として

1) 胸腺リンパ体質

2) 局所麻酔剂による中音

3) 術後性自家中毒

4) 神経系統の過剩症，あるい熼常刺战

5) その他

をあげ，かつ神経系統の過剰症，あるいは異常刺钱を重 要因子として指摘している。

これを臨床的に考察すれば，耳鼻咽喉和領域でもつと
むShock 発現率の多いと思われる 桃摘出術なぞにおけるいわゆる Novocain Shock と称 されるもの今本態は軨木 (安恒) ${ }^{48)}$ ，永瀬ら ${ }^{34)}$ の述ベ たこととく自律神経過剩刺钱，すなわち Reilly 現象によ り説明され，その㑂達経路の一つとして上頸部交感神経 節を介して束跕が中枢, 未梢えと伝わり, 全身諸藏器に 循環障碍を主とした変化を発来寸るのではないかとい ことも考它られる.

な特，当教室の玉川 ${ }^{28)}$ は電子頙微鏡学的に私と同様 な方法にて上頸交感神瑵節の检索を行つている。

\section{赫語}

1) 私以飯田の方法に従つてモルモツトロ唇にCroton 油を盾々の期間（2〜3時間，5日闌，10日間，20日間） 注射し, その際の口唇，上頸・腹腔交感神経節，内臟諸 㙎器の変化を病瑟租䋨学的に検索した。

2）日原は短時間群ではや〉浮聥状になり，長時間群 では瓌死, 䑤痕形成が著しい。

3）交感神経節は第 I 群（2〜3時間）ではほとえど变 化をみとめない，長特間群（5〜20日）では細胞体の萎

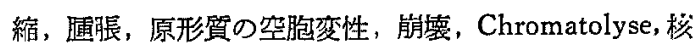
の腫脹, 菱縮変形, 崩壊などを主として退行変性をみと めた。剌㦸期間は長い程変化も强くなり，また上頸・腹 膑雨神経節とも同様な所見をみとめた。

4) 内葴々器には充醧血, 出血等の循澴系変化と退行 変性とをみとめ，特に第I群にてもつとも著しい。

5) 以上の 所見より口唇刺战の際に 発生する Shock 症状を Reilly 現象の王場より説明し，この伝達娃路の 一つとして上頸交感神経笛を介して全身の自律神経系に およぶ刺㥂を考えた。

6) さらに臨床的に Novocain Shock の原因导 Reilly 現象の立場から言及した。

\section{文献}

1) Abrikossoff: Virch. Arch. Bd. 240, S. 281, 1923.

2) Aoyagi: Dtsch. med. Wsch. Bd. 37, H. 1, S. 48, 1911. 3) Chauchard: L'Equilibre Symathique (山口・鈴木・安田共訳：植物神経之生体反灾, 由水 社, 骝 32). 4) Claude Bernard: Introduction à l'étude de la medicine experimentale (三浦贷栄訳: 実験医学入門, 興学会, 昭6). 5) Herzog: Cblt. f. path. Anat. Bd. 41, S. 301, 1928. 6) Herzog: Cblt. f. path. Anat. Bd. 45, S. 145, $1929 . \quad 7)$ H. Laborit: Réaction organique a l'Agression et Choc, 1955. (山 口与一䍨：侵警に対する生体反応とショック，最新医 
学社). 8) Mallet.Guy: Pancreatites Chroniques Gauches, Masson Ed., Paris, 1943. 9) R.A. Marquezy, M. Ladet et P. Gauchier-Villars: Soc. Méd. Hôpit, de Paris, Mai 1938, p.p 923 930. 10) Mo. gilnizcky: Virch. Arch. Bd. 241, S. 298, 1923. 11) Müller: Die Lebensnerven, 1924. 12) J. Reilly: Comp. Rend. Soc. Biol., Tom, 148 (2), P. 1374, 1954. 13) H. Se'ye: The Story of Adaptatiossyn-

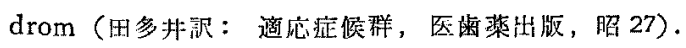

14) H. Se?ye: The textbook of Endocrinology, 第 I版，1947.（田多茾訳：七y王新内分泌学，医落薬出 版)， 15) A.D. Speransky: A Basis for the theory of Medicine, International Publischers Co. Inc., 1943. 16) Stöhr: Lehrbuch der Histology, 1928. 17) H. Stolze: Das obere Kreuz, J.F. Lehmanns Verlag, Müchen, 1953. 18) Terplan: Virch. Arch. Bd. 262, S. 431, 1926. 19) Uspenski: Allg. Zeits.

f. Psychiatrie, Bd. 53, S. 421, 1897. 20) Vis: Arch. f. Mikr. Anat., Bd. 40, S. 375, 1893. 21) C.J. Wiggers: Physiology of Shock, Common wealth Fund, New York, $1950 . \quad 22)$ Woh'wil!: Cblt. f. path. Anat., Bd. 45, S. 250, 1927 . 23) 浅見: 日 本外科宝函，5(5): 1048, 昭 3.24) 安楽：日本医大 雑誌，7(7)：653，(8)：847, 昭 11，25）陳：生休之 科学，1:33, 昭 24.26) 深沢：耳鼻咽喉科，30(3):

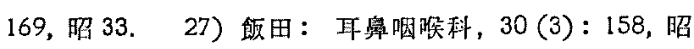
33. 28) 北手: 長崎医学雑誌, $8(3): 421$, 昭 5 .

29) 伊藤他：日本薬理学䧴誌, 53(2): 95, 昭 32. (会). 30) 小出: 媨已神経, $3(4): 200,(6): 339$, 眧 26 .

31) 足, 沖中: 自律神経系総論, 改言 6 版, 金原出版,

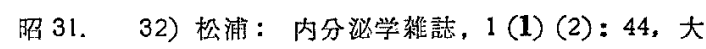
14. 33) 守屋：岡山医学雑誌, $48(11): 2603$, 昭 11 . 34) 永瀨：日耳会袁，61(9)：1480，昭 33.35$)$ 永

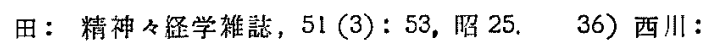
脳之神経, $3(4): 196$, 昭 26,37 ) 西端, 宮部, 倉井 他：人口蓋粘膜及び下甲介粘膜の 神経分布にっいて， 日耳第 60 回総会, 炤 34 . 38) 大沼：神経学雑誌, 30 (2): 115, 佋 4. 39) 沖中：生体の科学, 1:35, 昭

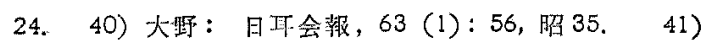

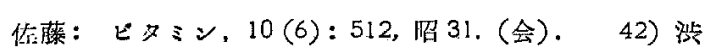

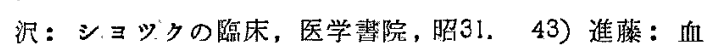
清反応とその実際, 医学整院, 昭 31.44) 白石他: 日

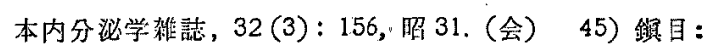

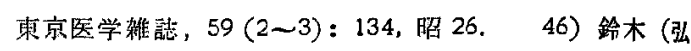
浩)，長嵿：感染症厄打る自律神経系の関与に関する 研究 (第3 赫)，第34 回伝染病学会, 昭 34, 47) 鉿木 (安恒) 他: 日仏医学, 3(4)：187, 昭 32. 48) 鈴本(安

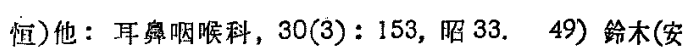
恒), 山口(英明) 他：耳臮咽喉科，30(8)：617，昭 33. 50) 鉿木 (安恒) 他: 耳䒜咽喉科展望, 2(2): 124, 昭 34,51) 鈴木 (安恒), 高崎, 鈴木 (辟司) 他：

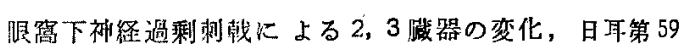

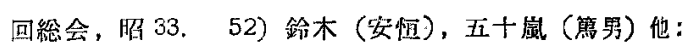
起腎炎性並びに非起简炎性溶連菌注射によるモルモット の緊変化 (レーロ一現象の観察)，日耳第60回総会，昭 34.53) 高楠：日新医学, $14(1): 71$, 大 13 , 54) 高 楠：神経学雑誌， $24(7): 347$, 大 13 . 55) 高桶：神 経学雑誌，24(7)：341, 大 13. 56) 高爾：京都医学 倠誌, $22(4): 57.5$, 大 14 . 57) 竹内: 耳臨林, 51(8): 688, 昭 33，(会). 58) 玉川：モルモット口唇過利

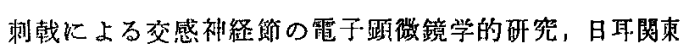
地方会第36 回大会, 昭 34.59）四多井:日本医師会谁 誌，37(8): 500, 昭 32. 60) 土展, 秋庭: 日本内分 泌学猚誌, $32(10): 110$, 昭 31. (会), 61) 上山：生 化学, $28(12): 788$, 昭 32. (会) 92) 山口: 最新医 学, $10(2): 158$, 昭 30 . 63) 山口: 日本医事新報, 1665 号：8, 昭31. 64) 山口 鹿応医学, $33(5)$ :

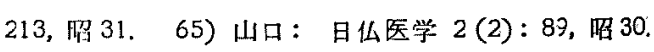

\section{付 図説 明}

第 1 図：肺澸 $\times 100$, Hämatoxylin-Eosin 染色, 脯

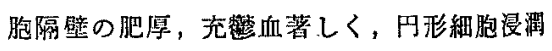
が萆明に見られる。

第 2 図: 肝茂 $\times 400$, Hämatoxylin-Eosin 染色, 充 毞血著しく，肝細胞の空胞变性がかなり見ら れる。

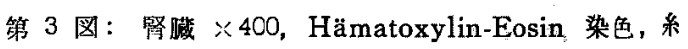

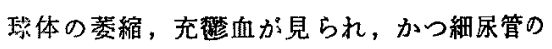
浮腆か゚みとめられる。

第 4 図: 融督 $\times 100$, Hämatoxylin-Eosin 染色, 血 管の充䇫血がみとめられる。

籁 5 図：第 I群口唇 $\times 100$, Hämatoxylin-Eosin 染 伯，皮下組織の浮腫が見られるが上皮炕は異 常は見られない。

第 6 図：第吕群口唇 ×100, Hämatoxylin-Eosin 染 色，上皮は脱落填死飞陷り，皮下組:織には線 

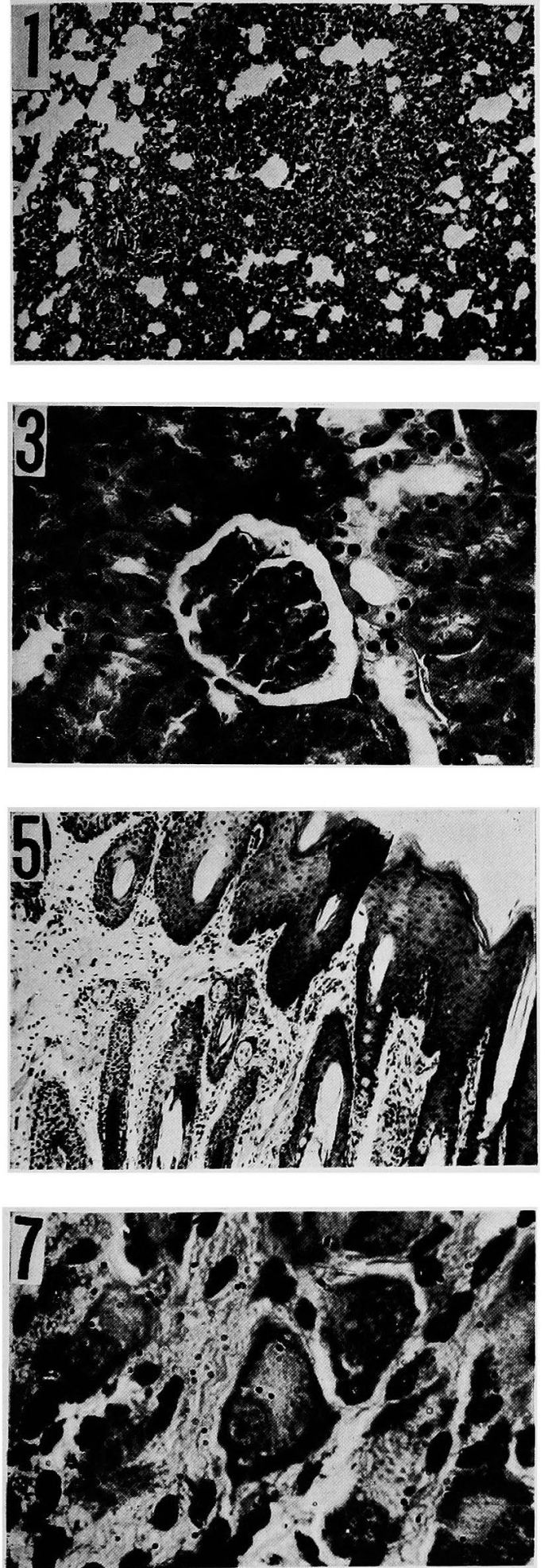
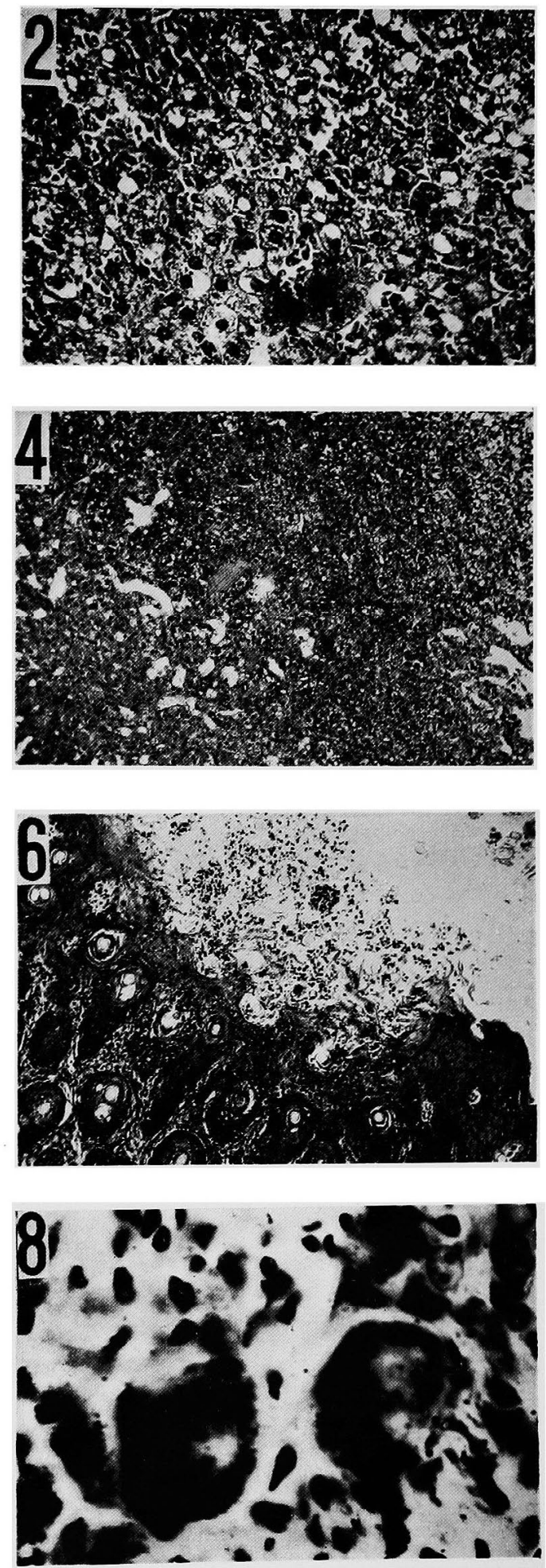
井上論文付図 (II)
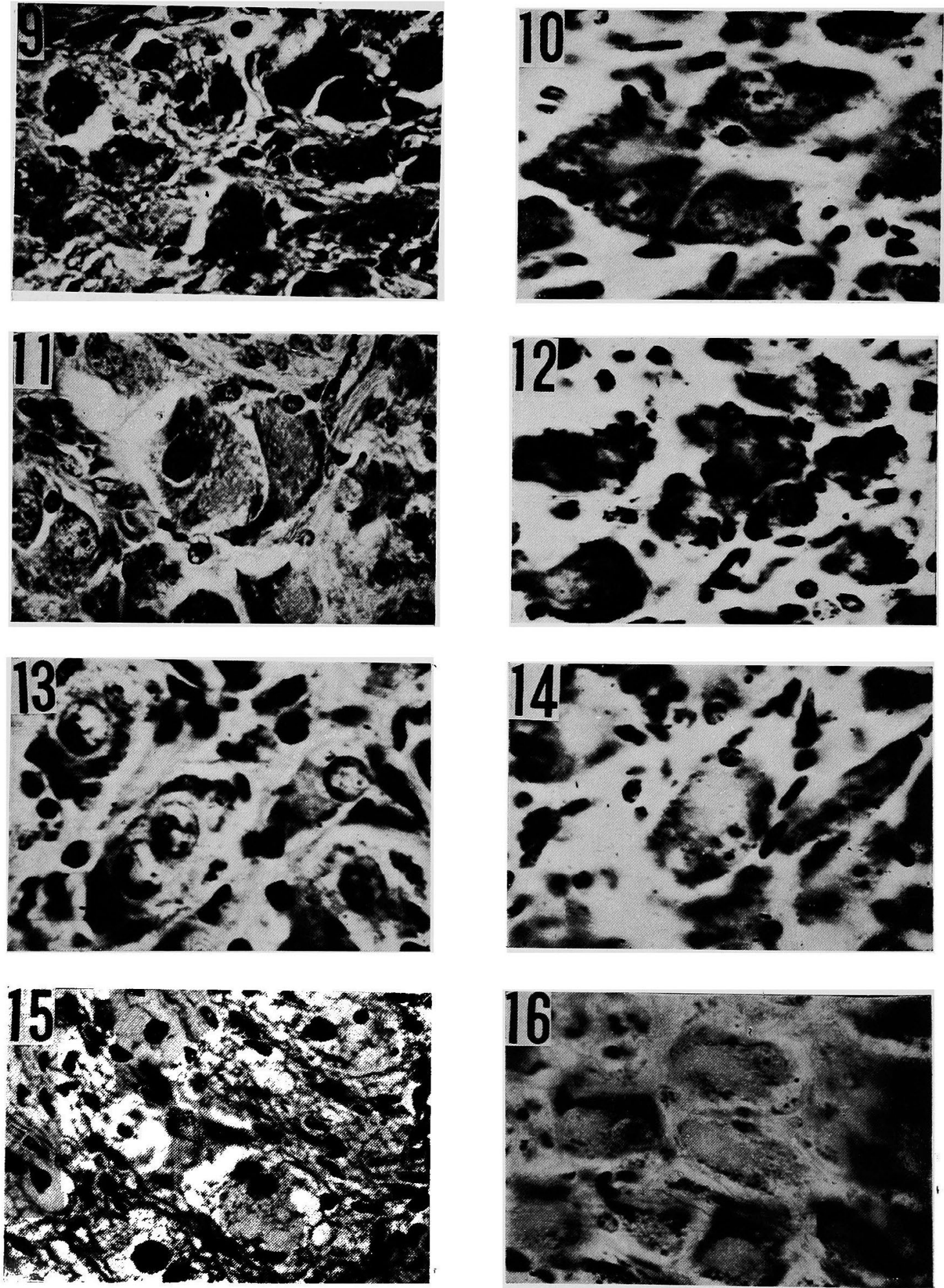
維化と円形絸胞漫潤がみとめられる。

第 7 図: 正常上靧袖経䬣 $\times 1000$, Hämatoxylin-Eosin 染色

第 8 図: 同上 $\times 1000, \mathrm{Nissl}$ 染色

第 9 図: 第 I 群上頸節 $\times 1000$, Hämatoxylin-Eosin 染色，神経節細胞の萎縮便化と小空胞が胃ら れる。

第10図：同上 $\times 1000, \mathrm{Nissl}$ 染臽，軽度の Chromatolyse と小空胞形成がみとめられる。

第 11 図：第】洋上頸節 $\times 1000$, Hämatoxylin-Eosin 染色，中心の細胞には腫脹，辺縁性崩墥が見 られる。

第12図：同上 $\times 1000, \mathrm{Niss}$ 染色，怪度の $\mathrm{Ch}$ romatolyse がみとめられる。

第 13 图：第吕群上䫫節 $\times 1000 ， H a ̈ m a t o x y l i n-E o s i n$ 染色，細胞体の崩填と核の軽い变化がみとめ られる。

第 14 図：第正群腹腔節 $\times 1000, N i s s l$ 染色，中等度の Chromatolyse とかなりの空胞形成がみとめ られる。
第，15図：第 $N$ 群腹腔筑 $\times 1000$, Hämatoxylin-Eosin

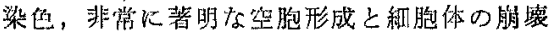
よが見られる。

籍 16 図：同士 $\times 1000, \mathrm{Niss}$ 染色，著明な Ch-

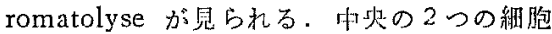
は Nissl 顆垃の消失がみとめられ，かつ小 空胞も見られる。

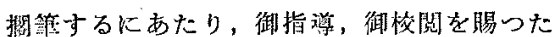

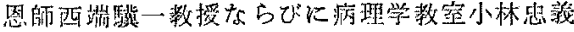

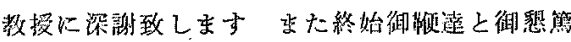
な御指等を戴きました鈴木灾恒助教授，さらに 病理学的検索に多大の御教示を睗つた病理山村

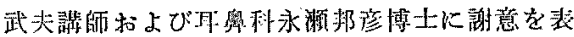
します

本諭交の要旨は眧和 34 作 4 月，日本耳舆咽 喉科学会関東地方会第 36 国大会に打いて 発表 した。

（原稿到篗 $=$ 昭和 34.11 ， 日） 